\title{
USING MUSIC TO TEACH LATIN AMERICAN (AND WORLD) HISTORY
}

\author{
Daisy V. Dominguez \\ The City College of New York, CUNY
}

As a student of Latin American Studies and as a librarian, I have discovered that film is the preferred audiovisual teaching tool. Music did not feature in the classes I took; moreover, in discussions with librarians, I have found that those interested in audiovisual materials typically focus on film. ${ }^{1}$ This void has long been a curiosity to me because I knew, even as a child, how the music of artists like Ruben Blades, Silvio Rodriguez, and Mercedes Sosa could help bring Latin American history to life. Long before I opened up my first Latin American Studies text as an undergraduate, I learned about the disappearances and murder of dissidents in Latin America by listening to Blades' song Desapariciones (Disappearances). And his song Tiburón (Shark) helped me reflect on how the United States is perceived in Latin America. These musical tales piqued my interest and would later reinforce what I learned in class.

Teachers in other areas of history have documented how effectively they have used music as a fun, immersive, and memorable way to introduce and discuss topics and concepts. $^{2}$ As the librarian for Latin American Studies and Spanish and Portuguese Literature at the City College of New York (CCNY), I became curious about whether faculty in these subject areas incorporate music into their instruction. I conducted two online surveys on the use of Latin American music in college-level instruction in 2008 and 2010. I shared survey links with faculty at CCNY and on the H-LATAM listserv, which is devoted to Latin American History, ${ }^{3}$ as well as on Facebook and Twitter. What follows is a discussion of songs that survey respondents and I recommend for teaching particular themes and events in Latin American history. ${ }^{4}$

\section{Indigenous People in Latin America}

The Otavalo Indian group Ñanda Mañachi's spoken word song La Gran Marcha (The Great March) can easily be used to discuss the treatment of indigenous peoples,

\footnotetext{
${ }^{1}$ While a lot has been written on Latin American, Caribbean, and Latino music, not as much is written on how it is implemented in the classroom.

${ }^{2}$ Donna M. Binkiewicz, "Tunes of the Times: Historical Songs as Pedagogy for Recent U.S. History," The History Teacher, 39 (August 2006), 515-516.

${ }^{3} \mathrm{H}-\mathrm{LATAM}$ is a great and practical resource for faculty looking for recommendations on texts, films, and songs for use in classroom instruction.

${ }^{4}$ Respondents' names appear only if they were provided, and with permission.
} 
their history of resistance, and, interestingly, the relationship between the academic and Indian communities. This song begins not with an indictment of the usual culpritsgenerals, dictators, or the Church-but rather, academia:

... Anthropologists search our grandfathers' teeth. Sociologists take photographs of our traditional homes. Politicians formulate redeeming plans. And everyone multiplies bread on paper and reads the Declaration of Human Rights to us. But Juan still has no land. Pedro wears his only shirt ... Julián does not know how to write Julián. We know about the Alliance for Progress. We also know about the OAS and the UN. But signs and acronyms do not feed us. ${ }^{5}$

La Gran Marcha criticizes aloof academics, politicians, and intergovemmental agencies (both from the North and South) that engage in work that purports to help Indians but which has often been materially useless to them. The sarcastic reference to "grandfathers" teeth" brings to mind Indian craniological photographs and could be used to introduce scientific racism, while the organizations listed can lead to a discussion on American aid to and intervention in the region.

\section{Afro-Latin American History}

Survey respondents suggested several songs for lectures on Afro-Latin American history and slavery. I have selected the two that seemed most promising in terms of showing the nuances in the historical experiences of Blacks in Latin America. One survey respondent recommended the music of the San Antonio Vocal Arts Ensemble (SAVAE) to discuss "transculturation," by which I think the respondent meant the interaction between and the melding of African, European, and indigenous cultural expressions during the Contact period (and possibly in contemporary Latin America as well). SAVAE has produced four CDs of colonial music by using native instruments and codices, which have allowed them to reconstruct pre-Columbian and other early colonial music by assigning pitches and drum patterns to syllabic notations. They sing in indigenous (Nahuatl and Quechua) and West African languages in addition to Spanish and Portuguese. Some of these songs are sung from an African perspective and allude to the intercultural nature of Black life in seventeenth-century Mexico. SAVAE Artistic Director Christopher Moroney notes that the song Eso rigor e repente, written by Portuguese musician Gaspar Fernandes, not only gives voice to Afro-Mexicans vis-

${ }^{5}$ Unless otherwise noted, all translations are my own. 
à-vis white society and an imposed religion, but also alludes to interethnic tensions between Africans. ${ }^{6}$ The lyrics read:

But although the child (Jesus) was born a little white one, we all amount to brothers. We have no fear of the big white one ... Tonight we'll all be white! ... Let's go, Guinean blacks, to the little manger by ourselves. Don't let the Angolan blacks go because they're all ugly blacks. We want the child to see only polished and handsome blacks...?

This song is impressive for the themes it combines. Africans both lament and recognize their distinctiveness in a white-dominated society, but they make reference to Christianity's ideal of brotherly love as a way to level the playing field. If they are not accepted based on this tenet, through performance, they can undergo a temporary transmutation as whites, or criollos. This reference could be used to introduce the fluidity of race in Latin America, which has historically not been contingent on biological traits but on other factors, such as social class, legal status, and even clothing. This song is also striking because it alludes to the heterogeneity of Black culture, even going back to the period of Contact, when people could more easily trace their ancestry to specific ethnic groups in Africa. The act of positioning one's ethnic group against another to vie for a better position in a white dominated culture can work as a segue for discussing Black agency, social mobility, and distinctions between slavery in areas colonized by the English and the Spanish or Portuguese.

Brazilian musician Jorge Ben's song Zumbi, in homage to the famed quilombo warrior and leader Zumbi of Palmares, ${ }^{8}$ is recommended for classes discussing Africans and plantation economies. Quilombos, or maroon communities, were made up of runaway slaves in Brazil, and Palmares was likely the most famous. Indeed, another respondent uses Gilberto Gil's song Quilombos as an "example of the present-day mythology surrounding the quilombo of Palmares." The song Zumbi begins with a list of the African cities that the slaves, now being sold at auction, come from. The song evokes the incongruities of the slave system: a princess and her subjects being sold next to "cotton so white" reaped by "black hands" that would not benefit from the profits. In the face of this injustice, the chorus sings "I want to see, I want to see, I want to see" and Ben replies, "What will happen when Zumbí arrives / Zumbí is the lord of war ...

\footnotetext{
6"La Noche Buena: Christmas Music of Colonial Latin America," SAVAE, http://www.savae.org/ noche.html (accessed February 8, 2014).
}

${ }^{7}$ Tbid. SAVAE's translation.

${ }^{8}$ Scott Ickes, "Zumbí of Palmares (1655-1695)," in Encyclopedia of the African Diaspora: Origins, Experiences, and Culture, Volume 3, ed., Carole Boyce Davies (Santa Barbara, CA: ABC-CLIO, 2008), 1009-1010. Gale Virtual Reference Library (accessed February 14, 2012). 
When Zumbi gets here it's Zumbí who calls the shots." Although this is a reference to his military leadership and the might of the quilombo, it is interesting to note that outsiders depended on the maroon community of Palmares for trade and vice versa. ${ }^{9}$ This song presents a great opportunity to get students thinking about the complexity of the slave experience and the ambivalent relationships that it produced.

\section{Repression}

The Rúben Blades song Desapariciones (Disappearances) is a device to introduce the Dirty War in Argentina, although it might be used to teach about repression in other countries as well. Desapariciones is sung from the perspective of relatives inquiring about the whereabouts of their "disappeared" loved ones, the thousands of people who were kidnapped, tortured, and killed during military dictatorships across the Southern Cone. The song ends with a chilling visual of the matter-of-fact way that these kidnappings took place: "Last night I heard various explosions / Shotgun and gun shots / Cars speeding, brakes, screams / Echoes of boots on the street / Knocking on doors, protests, 'by Gods,' broken plates / The soap opera was on so no one looked outside." Released just one year after the Dirty War ended, the song's emotive last words about the scarred memories of survivors might have served as a catalyst for those seeking justice for impunity and present an opportunity to introduce students to activist groups like the Mothers of the Plaza Mayo who seek justice for their disappeared children:

Where do the disappeared ones go?

Look for them in the water and in the bushes

And why do they disappear?

Because we are not all equal

And when will the disappeared one return?

Every time you remember him or her

How do you speak to the disappeared?

With wrenched emotion from deep within.

Blades' song El Padre Antonio y el Monaguillo Andrés (Father Anthony and his Altar Boy Andrew) will be of interest to those studying civil wars in Central America and El Salvador in particular. The song memorializes Salvadoran archbishop Oscar Arnulfo Romero who spoke out against military repression before his assassination in

\footnotetext{
${ }^{9}$ Judith L. Allen, "Palmares," Encyclopedia of Latin American History and Culture, eds., Jay Kinsbruner and Erick D. Langer, $2^{\text {nd }}$ ed., Vol. 5 (Detroit: Charles Scribner's Sons, 2008), 20-21. Gale Virtual Reference Library, Web (accessed September 27, 2012).
} 
1980 by a government backed right-wing death squad. ${ }^{10}$ The song is surprisingly upbeat considering that it deals with a murder until you hear the closing message: Romero's death will not be in vain for he represents Central America's and, more widely, Latin America's plight out of violence and corruption:

But the bells ring again for Father Anthony and his altar boy Andrew

The bells ring / the earth will shake

The bells ring / for America ...

The bells ring / Oh Our Lady Virgin

The bells ring / who will save us now? ...

The Central American bells ring

The bells ring / for my sister land ...

The bells ring / to celebrate

The bells ring / our liberty

The bells ring / because a united people

The bells ring / will never be defeated ...

The bells ring / for a good priest

The bells ring / Arnulfo Romero ...

The bells ring / of liberty

The bells ring / for America

The song is also unique because it refers to a member of the Church in a positive way and therefore can be used to discuss Catholic activism in El Salvador specifically ${ }^{11}$ and the influence of Liberation Theology in Latin America more broadly.

For this category, survey participants most frequently reference Victor Jara, whose name is synonymous with nueva canción, a genre that revived traditional folk music in 1960s Chile and featured indigenous instruments with modern lyrics. ${ }^{12}$ This genre is closely associated with grassroots movements: For instance, it was popular among supporters of the Chilean socialist president Salvador Allende. With the spread of military dictatorships beyond Chile, however, censors banned nueva canción and

\footnotetext{
${ }^{10}$ The 2011 Annual Register: World Events 2010, "El Salvador President's Speech on Anniversary of Murder of Archbishop Romero," http://ccny-proxyl.libr.ccny.cuny.edu/login?url=

$\mathrm{http} / /$ www.credoreference.com/entry/pqar/el_salvador_president_s_speech_on_anniversary_of_murder_ of_archbishop_romero (accessed January 2, 2013).

${ }^{11}$ Ralph Lee Woodward, Jr., "El Salvador," Encyclopedia of Latin American History and Culture, eds., Jay Kinsbruner and Erick D. Langer, $2^{\text {nd }}$ ed., Vol. 3 (Detroit: Charles Scribner's Sons, 2008), 88-97. Gale Virtual Reference Library, Web (accessed September 26, 2012).

${ }^{12}$ Jane Tumas-Serna, "The "Nueva Canción' Movement and its Mass-Mediated Performance Context," Latin American Music Review, 13, no. 2 (1992), 146-147.
} 
other music because of, allegedly, political and sexually explicit lyrics. ${ }^{13}$ Musicians were imprisoned, were exiled, or emigrated, the latter helping to spread the genre worldwide. Jara himself was tortured and killed following the coup that ousted Allende in Chile on September 11, 1973 (which in Latin American circles is referred to as "the other 9/1 1"). Professor Matthew Casey, now at the University of Southern Mississippi, recommends Jara's Manifesto as a vehicle for "a larger discussion of support for Allende and repression by Pinochet." Jan Fairley notes that although nueva canción is sometimes referred to as protest music, it often does not have an overt political message, but rather deals with topics that touch all of humanity and therefore inspire solidarity. ${ }^{14}$ This might be true of the song Manifesto, which does not refer to specific events or people but rather speaks in poetic and general terms about the right of the poor to speak their mind and talk about the truth:

\section{I sing because the guitar}

Has feelings and reason

It has an earthy heart and a dove's wings ...

Working guitar

with a spring-like smell

It's not a rich man's guitar ...

My song is that of the scaffolds ...

of those who will die singing truths...

There where everything goes

And where everything begins

A brave song

will always be a new song (nueva canción).

Professor Donald Ramos, formerly of Cleveland State University, notes using MPB, or Musica Popular Brasileira, and Chico Buarque's music in particular to study the tropicália genre and social protest. MPB primarily refers to Brazilian urban popular music from the late 1960s, which has acoustic instrumentation and was initially highly

\footnotetext{
${ }^{13}$ The Argentinean government banned not only songs by Victor Jara and other Latin American artists but also some pop and rock songs by American artists; see this official memorandum: http:/www.comfer.gov.ar/web/blog/wp-content/uploads/2009/07/canciones-prohibidas1.pdf. Rory Carroll, "How Pink Floyd spelled trouble for Argentina's military junta," The Guardian, August 6, 2009, http://www.guardian.co/uk/world/2009/aug/06/argentina-junta-banned-songs-poptihistory-byline (accessed October 17, 2011). Enylton De Sá Rego and Charles A. Perrone, MPB: Contemporary Brazilian Popular Music (Albuquerque: The Latin American Institute University of New Mexico, 1985), 10 .

${ }^{14} J a n$ Fairley, "Cuba - Trova and Nueva Trova: Troubadours Old and New," in World Music the Rough Guide Volume 2: Latin \& North America, Caribbean, India, Asia and Pacific, eds., Simon Broughton and Mark Ellingham (London: Rough Guides, 2000), 408.
} 
influenced by Brazilian musical traditions, but by the 1970 s, was also influenced by international music. ${ }^{15}$ One of its most controversial genres is tropicália, or tropicalismo, a socially conscientious genre that used contrasts and contradictions to critique the middle class and European cultural impositions, even as the genre was influenced by foreign music. ${ }^{16}$ Though specific songs are not mentioned in the surveys, the song Calice, which defends the common man and critiques the military dictatorship, would be a good way to introduce this period of human rights abuses and censorship in Brazilian history (1965-1985) ${ }^{17}$ Inventive and subtle lyrics were a necessity at a time when music was censored and lyrics had to be approved by the Brazilian Federal Censorship Bureau. ${ }^{18}$ Brian Hodel notes that in Portuguese, the word "chalice" is pronounced the same way as the word "shut up."19 This play on words and the song lyrics deal with the difficulty of living under a repressive regime: "How hard it is to wake up gagged, / After having gone mad in the silence of the night. / I want to let out an inhuman cry. / It's a way to be heard." 20

\section{Identity}

One of the songs that can be used to introduce the topic of identity in Latin America is Ruben Blades' Buscando América (Searching for America). ${ }^{21}$ Because the history of Latin America has been marred and influenced so strongly by dictatorships and the resultant torture, disappearance, and murder of so many, to speak of this topic is a poignant way to rally people from the region to a common pain and history. This song was released in 1984, the year after Argentina's Dirty War ended and at a time

\footnotetext{
${ }^{15}$ Charles Perrone, Masters of Contemporary Brazilian Song (Austin: University of Texas, 1989), x.

${ }^{16} \mathrm{Gerard}$ Béhague, "Brazilian Musical Values of the 1960s and 1970s: Popular Urban Music from Bossa Nova to Tropicalia," Journal of Popular Culture, 14, no. 3 (1980), 448-449.

${ }^{17}$ Brian Hodel, "Censorship and Creativity in Brazilian Popular Music," Progress Reports in Ethnomusicology, 2, no. 9 (1989), 12.

${ }^{18} \mathrm{Hodel}$, "Censorship and Creativity in Brazilian Popular Music," 1-15. David Cleary, "Brazil: meu brasil brasileiro," in World Music The Rough Guide Volume 2: Latin \& North America, Caribbean, India, Asia and Pacific, eds., Simon Broughton and Mark Ellingham (London: Rough Guides, 2000), 340 .

${ }^{19}$ Translation by Hodel, "Censorship and Creativity in Brazilian Popular Music," 13.

${ }^{20} \mathrm{Ibid}, 10$.

${ }^{21}$ Here, the term America refers to the Americas and specifically Latin America.
} 
when Central America was in civil war. The lyrics refer to dictatorships and torture but also to a dream of rallying once again as a single people:

While there is no justice, we will never have peace

Living dictatorships, I search for you and don't find you

They don't know where / your tortured body is.

Argentina! Salvador! Guatemala! Paraguay! Chile!

If the dream of one is the dream of us all

Break the chains and walk

Let's be confident

Let's move on, my people ...

They have kidnapped you, America

And gagged your mouth

Not it's up to us to liberate you

I'm searching for you, America

Our future awaits

And before it dies

We will find you

Another Blades' song that deals with Latin American identity is Plástico (Plastic). This song exalts Latin American beauty and values and warns against "imported models that are not the solution." After listing the ways that a woman and man live a plastic (read: false) life, including counseling their son not to play with kids that are "strangely colored," the song appeals to Latin Americans to value themselves and the truth: "Listen Latin American, listen brother, listen friend. Never sell your destiny for gold or convenience ... Let's all move forward together so we can end the ignorance which influences us, stop using foreign models that are not the solution." The song speaks of Latin Americans as "a united race / the one [Simón] Bolivar dreamed of" and ends with Blades calling attendance for all of Latin America in a call and response format: "Panamá! Presente! (Panama! Here!)," etc.

Survey respondents also recommended Mercedes Sosa's moving song Todas las voces, todas (All the Voices, All of Them) to discuss identity. Like Plástico, this song calls on various South American countries and their united dreams through their unified voices. Sosa praises the beauty and bounty of Latin America ("I set out to walk / through the cosmic belt of the south ... a green Brazil kisses my Chile of copper and minerals"). Because of its references to the continent's natural and mineral wealth, the song also presents an opportunity to talk about Latin America commerce and neoliberal policies. 


\section{Immigration, Diaspora \& Exile}

The norteño band Tigres del Norte was very popular among survey respondents. This group's repertoire lends itself to an engaging discussion on the complexities of the immigration issue. Tres veces mojado (Wet Three Times), for example, deals with the plight of undocumented immigrants, and more specifically those Central Americans who, unlike Mexicans, must cross three national boundaries to get to the United States. This comparison could be used to segue into a discussion on relationships among Latin Americans of different nationalities. While those exposed to U.S. media are accustomed to hearing about Mexicans being detained by Americans, Central Americans are both helped by Mexican immigrants and coyotes but also must fend off Mexican authorities. Jaula de Oro (Golden Cage) deals with the paradox of undocumented immigration, which brings material wealth but leaves immigrants feeling a sense of loss for their mother country and alienation from children who feel more American than Mexican. In the song, a father asks (in Spanish), "Son, would you like us to go back to Mexico?" The son replies (in English), "What you talkin' about dad? I don't wanna go back to Mexico. No way, dad." The father continues, "My kids don't speak to me. They have learned another language. They have forgotten Spanish. They think like Americans. They deny they are Mexican although they have my color." The song Somos mas americanos (We are More American) reframes the debate over illegal immigration from a Mexican perspective:

I want to remind the gringo. I didn't cross the border. The border crossed me. America was born free. Man divided it. They painted the line so that I would have to jump it and now call me an invader ... They took eight states away from us. Who here is the invader? ... And if we count by century, even though it hurts our neighbor [to admit it], we are more American than all the gringos.

Faculty cited Cateano Veloso's song London, London when teaching about exile and this song is an interesting counterpoint to the Tigres del Norte songs about the plight of Latin American immigrants in the United States. Veloso, who went into exile in London in the late 1960s, sings not of a hostile host city, but a peaceful London with friendly policemen. The chorus "While my eyes go looking for flying saucers in the sky" seems to be a reference to the strangeness of being in such a peaceful, free place with friendly authority figures.

\section{How to Find More Songs}

Survey respondents suggested many other musicians, often without naming specific songs or to what end these songs were used in class. While the H-LATAM 
listserv members are very helpful in suggesting appropriate music for a given theme, these are posted only upon request. Ideally, educators would have a resource where they could search for music at any time. One survey respondent welcomed a suggestions database as a way to learn about music. As a result, I have started a rudimentary Omeka database called Teach with Music that allows educators to submit information on songs that they recommend for use in classroom instruction. ${ }^{22}$ To access Teach with Music, visit http://daisilla.org/omeka. Currently, each song record contains subject headings, an explanation of how a song is used in instruction, the name of the song writer/singer, the song's language, the country of origin, tags, and the name of the person who submitted the record information. The website currently only includes Latin American songs suggested by Matthew Casey and Marisa Pereyra of Immaculata University, but I welcome submissions for songs on any area of history. I envision Teach with Music becoming even more useful if developed to be interoperable with websites such as YouTube or Grooveshark, so that users can seamlessly link and listen to the songs they discover in the database. Linking Teach with Music to websites such as Wikipedia and scholarly databases would also lead users to important historical contextualization for the references made in songs and critical scholarship on artists and genres. I hope this essay has encouraged readers to reflect on what music has to offer their historical areas of specialization and piqued your interest in visiting Teach with Music and using music as another method of teaching history.

\footnotetext{
${ }^{22}$ Many thanks to CUNY Digital Humanities Initiative members Charlie Edwards, Scott Voth, and Aaron Knoll for their guidance and technical assistance.
} 